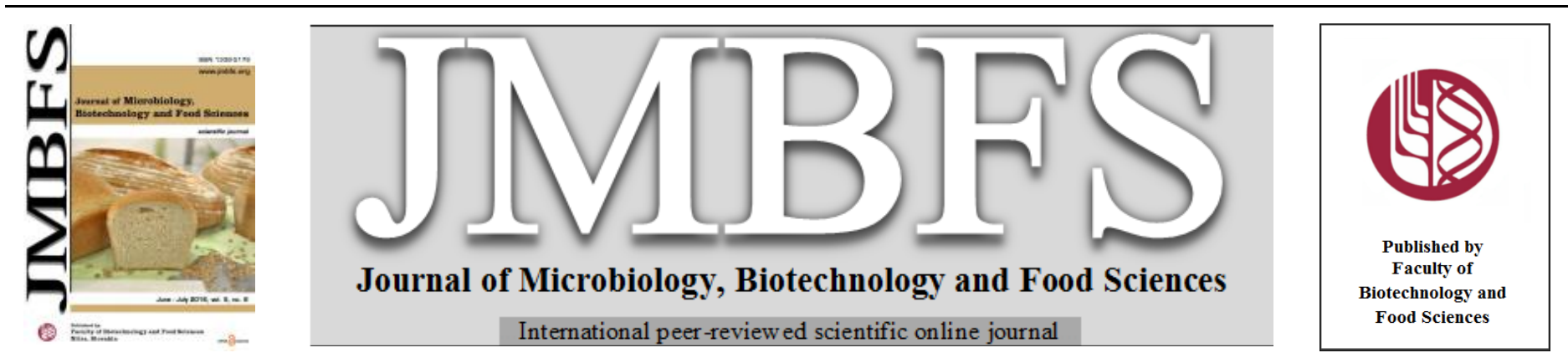

\title{
APPLICATION OF RYE SSR MARKERS FOR DETECTION OF GENETIC DIVERSITY IN TRITICALE
}

\section{Želmíra Balážová*, Zdenka Gálová, Martin Vivodík}

Address(es): Mgr. Želmíra Balážová, PhD.,

Slovak University of Agriculture in Nitra, Faculty of Biotechnology and Food Sciences, Department of Biochemistry and Biotechnology,

Tr. A. Hlinku 2, 94976 Nitra, Slovak Republic, +421376414327.

*Corresponding author: zelmira.balazova@uniag.sk

doi: 10.15414/jmbfs.2016.5.6.623-626

\section{ARTICLE INFO}

Received 24. 2. 2016

Revised 6. 4. 2016

Accepted 14. 4. 2016

Published 1. 6. 2016

Regular article

open $\partial_{\text {access }}$

\begin{abstract}
Present study aims to testify usefulness of particular rye SSR markers for the detection of genetic diversity degree in the set of 20 triticale cultivars coming from different European countries. For this purpose, a set of six rye SSR markers were used. The set of six polymorphic markers provided 22 alleles with an average frequency of 3.67 alleles per locus. The number of alleles ranged between 2 (SCM43) and 5 (SCM28, SCM86). Resulting from the number and frequency of alleles diversity index (DI), polymorphic information content (PIC) and probability of identity (PI) were calculated. An average value of PIC for 6 SSR markers was 0.505 , the highest value was calculated for rye SSR marker SCM86 (0.706). Based on UPGMA algorithm, a dendrogram was constructed. In dendrogram cultivars were divided into two main clusters. The first cluster contained two cultivars, Russian cultivar Greneder and Slovak cultivar Largus, and second included 18 cultivars. Genetically the closest were two Greek cultivars (Niobi and Thisbi) and were close to other Greek cultivar Vrodi. It was possible to separate triticale cultivars of spring and winter form in dendrogram. Results showed the utility of rye microsatellite markers for estimation of genetic diversity of European triticale genotypes leading to genotype identification.
\end{abstract}

Keywords: Triticale, microsatellites, polymorphism, dendrogram

\section{INTRODUCTION}

Triticale (x Triticosecale Witt.) is the intergeneric hybrid between wheat and rye, has gained considerable importance in recent years in Europe (Tams et al., 2004). It combines desirable traits of both parents (Salmanovicz et al., 2013). It is a crop with broad genetic potential and is widely adapted to abiotic stress conditions such as aluminium toxicity, drought, salinity, acidic or waterlogged soils (Kuleung et al., 2004). Triticale is also resistant to different diseases of wheat (Leonova et al., 2005). Triticale constitutes a valuable genetic resource for transferring genes of interest from rye into wheat, particularly those related to biotic and abiotic stresses (Vaillancourt et al., 2007). Knowledge of germplasm diversity has a significant impact on the improvement of crop plants. Molecular markers can provide an effective tool for efficient selection of desired agronomic traits because they are based on the plant genotypes and thus, are independent of environmental variation. Nowadays, several molecular markers are developed, of which simple sequence repeats (SSRs) or microsatellites are the most widely used types (Benor et al., 2008). SSR markers were successfully used for many purposes, such as mapping (Tams et al., 2004; Bickel et al., 2011), testing the authenticity of genetic stocks (Pestsova et al., 2000) and tagging resistance genes (Peng et al., 1999). Simple sequence repeat (SSR) markers show a relatively good transferability between closely related species (Botes \& Bitalo, 2013) and they are one of the most promising molecular marker types to identify or differentiate genotypes within a species (Salem et al., 2008). They were sucessufully used in many plant species, e.g. wheat (Röder $\boldsymbol{e t}$ al., 1995; Huang et al., 2002, Gregáňová et al., 2005, Hudcovicová et al., 2013), rye (Khlestkina et al., 2004, Balážová et al., 2016), triticale (Kuleung et al. 2004; Tams et al., 2004, da Costa et al., 2007; Odrouškova \& Vyhnanek, 2013, Balážová et al., 2015), rice (Jiang et al, 2010), maize (Ignjatovic-Micic et al., 2015), and flax (Bickel et al.,2011).

The aim of this study was to testify usefulness and transferability of six rye SSR markers to triticale (x Triticosecale Witt.) and detect a genetic variability among a set of twenty European cultivars.

\section{MATERIAL AND METHODS}

\section{Plant material and DNA extraction}

Twenty European triticale cultivars (x Triticosecale Witt.) were used for analysis (Table 1). Cultivars were provided by Gene Bank of Slovak Republic in Plant Production Research Center Piešt’any, Bratislavská 122, 92168 Piešt’any, Slovakia (12 winter triticale and 8 spring triticale). Samples originated from 6 countries: i.e. Germany (6), Spain (4), Slovakia (4), Greece (4), Czech Republic (1), Russia (1).

\section{DNA isolation}

DNA was isolated from $100 \mathrm{mg}$ freshly-collected leaf tissue according to GeneJET $^{\mathrm{TM}}$ protocol (Fermentas, USA). The concentration and quality of DNA was checked up on $1.0 \%$ agarose gel stained by ethidium bromide and detecting by comparing to $\lambda$-DNA with known concentration.

\section{PCR conditions}

For analysis, six microsatellite primer pairs were chosen according to the literature (Saal and Wricke, 1999). Used primers belong to rye-derived primers $(S C M)$ localised on $2 \mathrm{R}, 5 \mathrm{R}$ and $6 \mathrm{R}$ chromosomes (Table 2). PCR amplification was performed in $20 \mu 1$ volume containing PCR water, 5 x Green GoTaq $^{\circledR}$ Flexi Buffer, $100 \mu \mathrm{M}$ dNTP Mix, $0.3 \mu \mathrm{M}$ primers (Forward and Reverse primer), 1.5 $\mathrm{mM} \mathrm{MgCl} 2,0.4 \mathrm{U} \mathrm{GoTaq}^{\mathbb{8}}$ polymerase (Promega, USA). PCR reactions were performed in a thermocykler (Bio-Rad, USA) in $0.2 \mathrm{ml}$ tubes. The PCR program consisted of these steps: an initial denaturation $\left(1\right.$ cycle): 2 min. at $93{ }^{\circ} \mathrm{C},(29$ cycles) denaturation: $1 \mathrm{~min} .93{ }^{\circ} \mathrm{C}$, annealing $2 \mathrm{~min}$. with different temperature for each primer pair and extension $2 \mathrm{~min}$. at $72{ }^{\circ} \mathrm{C}$. 
Table 1 List of the used triticale cultivars

\begin{tabular}{lccc}
\hline No. & cultivar & country of origin & form \\
\hline 1 & Flavius & Slovakia & winter \\
2 & Largus & Slovakia & winter \\
3 & Pletomax & Slovakia & winter \\
4 & Kandar & Slovakia & winter \\
5 & Amarillo 105 & Germany & winter \\
6 & Trizeps & Germany & winter \\
7 & Mungis & Germany & winter \\
8 & Trimmer & Germany & winter \\
9 & Trigold & Germany & winter \\
10 & Cosinus & Germany & winter \\
11 & Senatrit & Spain & spring \\
12 & Sierra de Villuercas & Spain & spring \\
13 & Sierra de Almaraz & Spain & spring \\
14 & Tentudia & Spain & spring \\
15 & Kinerit & Czech Republik & winter \\
16 & Vrito & Greece & spring \\
17 & Niobi & Greece & spring \\
18 & Vrodi & Greece & spring \\
19 & Thisbi & Greece & spring \\
20 & Greneder & Russia & winter \\
\hline & & &
\end{tabular}

\section{Electrophoresis and staining conditions}

The PCR amplicons $(5 \mu \mathrm{l})$ were resolved by electrophoresis in $6.0 \%$ denaturating polyacrylamide gel and run with $1.0 \times$ TBE buffer. Electric voltage and time were different for each marker. The electric voltage ranged from 1800 to $2000 \mathrm{~V}$ and time of electrophoretic separation differs for each marker (3-4 hours) influenced by the predicted size of fragments. After electrophoresis, gels were fixed and stained with silver according to ${ }^{[22]}$. Final PCR amplicons were scanned in UVP PhotoDoc- $\mathrm{t}^{\circledR}$ camera system. The size of alleles was determined by comparing with $10 \mathrm{bp}$ standard lenght marker (Invitrogen: 100-330 bp). Each band was treated as a single allele.

\section{Data analysis}

For statistical evaluation, all gels were scored in a binary matice on the base of presence (1) or absence (0) of particular allele. Information about presence of alleles and their frequency were used for calculation of Jaccard coefficient of genetic similarity by SPSS modul (SPSS inc., USA). Final dendrogram was constructed by hierarchic cluster analysis using UPGMA (Unweighted Pair Group Method using arithmetic Averages) algorithm by SPSS statistic programme version 17.

For the assessment of the polymorphism between triticale genotypes and usability of SSR markers for differentiation we used diversity index (DI) (Weir, 1990), the probability of identity (PI) (Paetkau $\boldsymbol{e t}$ al., 1995) and polymorphic information content (PIC) (Weber, 1990).

They were calculated according to formulas:

Diversity index (DI)

$D I=1-\sum p_{i}^{2}$

Probability of identity (PI)

$P I=\sum p_{i}^{4}+\sum_{i=1}^{i=n-1} \sum_{j=i+1}^{n}\left(2 p_{i} p_{j}\right)^{2}$

Polymorphic information content (PIC)

$P I C=1-\left(\sum_{i=1}^{n} p_{i}^{2}\right)-\sum_{i=1}^{n-1} \sum_{j=i+1}^{n} 2 p_{i}^{2} \cdot p_{j}^{2}$

where pi and pj are frequencies of ith and jth allele of given genotype.

Table 2 Sequences and melting temperature value (TM) of six SSR primers

\begin{tabular}{lclcc}
\hline SSR marker & $\begin{array}{c}\text { Locus on } \\
\text { chromosome }\end{array}$ & $\begin{array}{l}\text { Sequences of primers } \\
\text { 5' }^{\prime} \rightarrow \text { 3 }^{\prime}\end{array}$ & SSR repetition & $\begin{array}{c}\text { Annealing } \\
\text { temperature }\end{array}$ \\
\hline SCM28 & 6RL & $\begin{array}{l}\text { 5' CTGGTCCTGGTCTGGTGGGTC } \\
\text { 3' CGCATCGGGTGTGTCGCATAC }\end{array}$ & $(\mathrm{GT})_{26}$ & $60^{\circ} \mathrm{C}$ \\
SCM43 & 2RS & $\begin{array}{l}\text { 5' CTAGGGGATTACAGGGAGGGCA } \\
\text { 3' GTTCCCTTGTCCTACTCGTTACCG }\end{array}$ & $(\mathrm{GT})_{11}$ & $60^{\circ} \mathrm{C}$ \\
$\mathbf{S C M 8 6}$ & 6RL & $\begin{array}{l}\text { 5' CAGATAGATGGGTGTTGTGCG } \\
\text { 3' CTCTTCTCGACATCCACACTCC }\end{array}$ & $(\mathrm{GT})_{20}$ & $60^{\circ} \mathrm{C}$ \\
$\mathbf{S C M 1 2 0}$ & 5RL & $\begin{array}{l}\text { 5' CATTGTTGCGAGTGTTAAGC } \\
\text { 3' TGTGCTGTCGTCGATGTTGTC }\end{array}$ & $(\mathrm{AC})_{10}$ & $60^{\circ} \mathrm{C}$ \\
SCM180 & 6RL & $\begin{array}{l}\text { 5' GTTTCGTCCCCGTTGCCATC } \\
\text { 3' ACGTGTCGCTTTCCATTGCCC }\end{array}$ & $(\mathrm{GT})_{6}(\mathrm{GA})_{7}$ & $60^{\circ} \mathrm{C}$ \\
$\mathbf{S C M 2 6 8}$ & 5RS & 5' GCGCACCCCACACAACACG & $(\mathrm{CA})_{9}$ & $65^{\circ} \mathrm{C}$ \\
\hline
\end{tabular}

\section{RESULTS AND DISCUSSION}

Six SSR markers were used in this study with the aim to detect genetic diversity in triticale (x Triticosecale Witt.) cultivars. This work focused on two principal goals: i.e. a) to testify the usefulness and efficiency of 6 rye SSR markers in close-related triticale and $b$ ) to find out a genetic background among triticale cultivars (bred in different European countries). Six SSR markers provided a polymorphic spectrum.

A total of 22 alleles were detected (Table 3) with an average value of 3.67 alleles per locus. The number of alleles ranged from 2 (SCM43) to 5 (SCM28, SCM86) Very similar average number of detected alleles per locus was detected by authors Vyhnánek et al. (2009), Ondroušková \& Vyhnánek (2013) an Kuleung et al. (2004). Ondroušková \& Vyhnánek (2013) used 25 SSR wheat and rye SSR markers for the study of genetic variability in 10 triticale cultivars. They detected 84 alleles (3.36 alleles per locus). Vyhnánek et al. (2009) studied 16 genotypes of triticale using 48 markers (27 wheat and 21 rye SSR markers) and detected 184 alleles with an average of 3.83 alleles per locus. Kuleung $\boldsymbol{e t}$ al. (2004) detected on average 4.2 alleles per locus using 43 wheat and 14 rye SSR markers for the study of genetic diversity of 80 hexaploid accessions. Highe average number of alleles was detected by Tams $\boldsymbol{e t}$ al. (2004) ( 6.8 alleles and per locus). This value is considerably higher compared to our results, but it could be caused by higher number of SSR markers. The highest number of alleles (5) was detected by SSR marker SCM 28 and SCM86. Kuleung et al. (2006) detected the same number of alleles by SSR marker SCM268 (3) but lower number of alleles (3) compared to our results (4) by SSR marker SCM120.

As mentioned above, the usefulness of SSR markers is not influenced just by an overall number of detected alleles, but the most important factor is their distribution and frequencies. The way how to find out their effectiveness is to calculate Diversity index (DI), Polymorphic information content (PIC) and Probability of identity (PI) based on frequencies of alleles.

Diversity index (DI) for six rye SSR markers varied from 0.172 (SCM43) to 0.710 (SCM28, SCM86) with an average of 0.540. Kuleung et al. (2006) and Tams et al. (2004) calculated the same diversity index (0.54) for the study of genetic diversity of triticale cultivars using 57 SSR markers and 93 SSR markers, respectively. Ondroušková \& Vyhnánek (2013) calculated similar average diversity index (0.55). Higher values of DI (0.65) were reported by (Balážová $\boldsymbol{e} t$ al., 2015) who used wheat genomic SSR markers for the study of genetic diversity of triticale cultivars.

Polymorphic information content (PIC) varied from 0.157 (SCM43) to 0.706 (SCM86) with an average of 0.505 . An average value of PIC was similar compared to work Ondroušková \& Vyhnánek (2013) who reported on average 0.5 and Vyhnánek et al. (2009) who calculated 0.48. Probabilities of identity (PI) ranged from 0.044 (SCM86) to 0.699 (SCM43) with an average of 0.264 Korkovelos et al. (2008) claimed that the more effective SSR in discriminating among genotypes is the one having the higher PIC and DI along with lower 
PI values. According to this allegation, the most effective marker for the genetic diversity detection is SCM86. As appropriate markers, we also recommend SCM 28 and SCM180, respectively. Only one marker (SCM43) reached considerably unfavourable results of DI, PIC, PI and number of alleles compared to average values of tested set.

Table 3 Statistical characteristics of used primers

\begin{tabular}{lcccc}
\hline $\begin{array}{l}\text { SSR } \\
\text { marker }\end{array}$ & Number of alleles & DI & PIC & PI \\
\hline SCM28 & 5 & 0.710 & 0.689 & 0.074 \\
SCM43 & 2 & 0.172 & 0.157 & 0.699 \\
SCM86 & 5 & 0.710 & 0.706 & 0.044 \\
SCM120 & 4 & 0.534 & 0.500 & 0.237 \\
SCM180 & 3 & 0.607 & 0.532 & 0.222 \\
SCM268 & 3 & 0.505 & 0.444 & 0.305 \\
\hline average & 3.67 & 0.540 & 0.505 & 0.264 \\
\hline
\end{tabular}

DI - Diversity index; PIC - Polymorphic information content; PI - Probabilities of identity

Resulting from number and frequencies of alleles, a UPGMA dendrogram based on Jaccard's coefficient of similarity was constructed (Figure 1). Dendrogram revealed genetic relationships among analysed set of winter and spring triticale genotypes. Cultivars were divided into two main groups (1 and 2). First cluster (1) contained two cultivars, Slovak cultivar Largus and Russian cultivar Greneder. Second cluster of 18 cultivars was further subdivided into two subclusters ( $2 \mathrm{a}$ and $2 \mathrm{~b}$ ), subcluster $2 \mathrm{a}$ included 11 triticale cultivars and subcluster $2 b$ contained 7 cultivars. All (4) Greek cultivars were included in subcluster $2 \mathrm{~b}$. Genetically the closest were two Greek cultivars, Niobi and Thisbi from subcluster $2 \mathrm{~b}$. We can consider their close genetic background. Another Greek cultivar Vrodi was also placed nearby Niobi and Thisbi. Most of cultivars from subcluster $2 \mathrm{~b}$ are of spring form (85.7\%). Subclusters 1 and 2a comprised predominantly of winter triticale cultivars $(84.6 \%)$.

Vyhnánek et al. (2009) tested set of 16 accessions using 48 SSR markers. One Russian genotype had been significantly differentiated from all set of accessions. Da Costa et al. (2007) divided 54 accessions of triticale based on wheat SSR markers into seven main groups using UPGMA dendrogram based on Jaccard's coefficient of similarity. Since most of the analyzed germplasm was derived from Mexican triticale, they detected a high similarity among triticale cultivars and moderate variability.

Kuleung et al. (2004) and Tams et al. (2004) reported that the diversity revealed by rye SSR markers in triticale was lower in comparison to wheat microsatellites. We can confirm this statement by our earlier study (Balážová et al., 2015) where we have detected higher average values of PIC and DI of used wheat SSR markers to study genetic diversity of triticale cultivars compared to today's study with rye SSR markers.

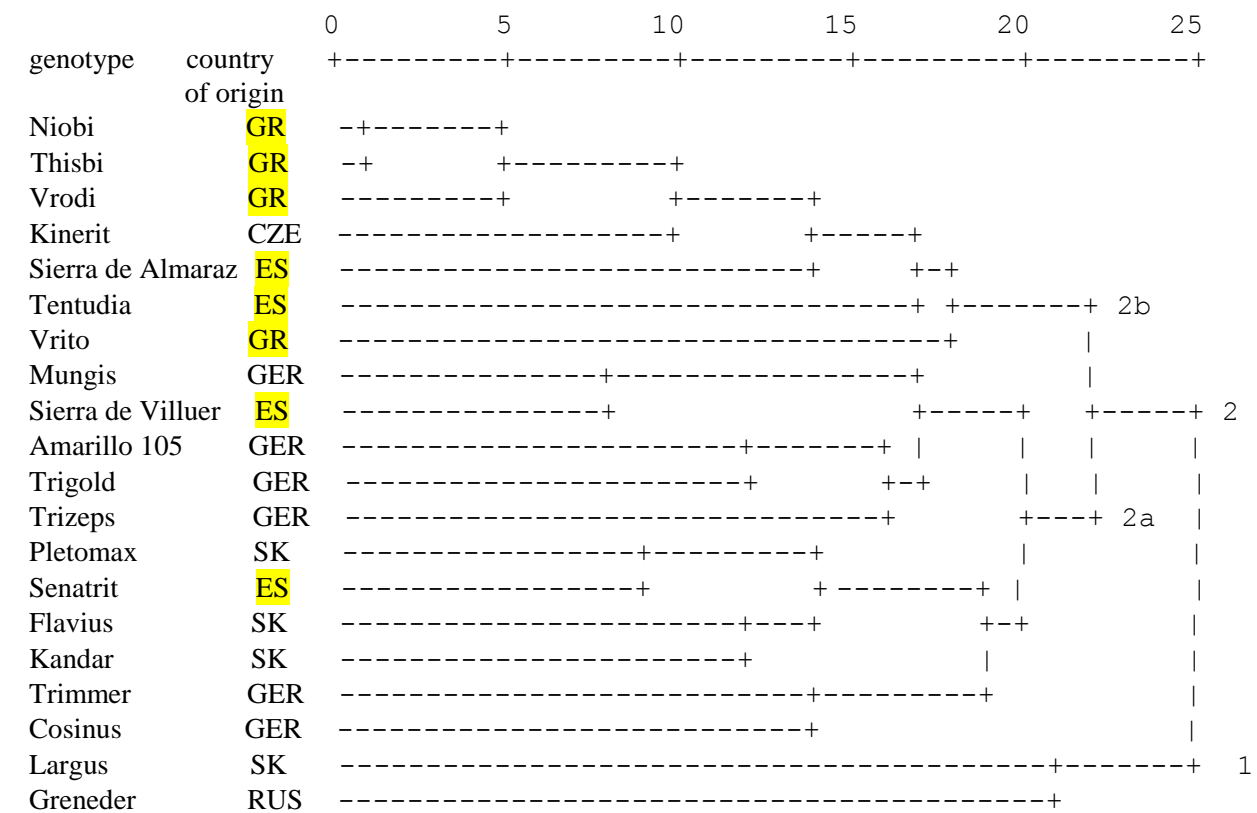

Figure 1 Dendrogram of 20 triticale genotypes based on data from six rye SSR markers. Yellow labelled cultivars are of spring form

\section{CONCLUSION}

A tested set of six rye SSR markers allowed significantly distinguish 18 out 20 cultivars. Only two Greek cultivars, Niobi and Thisbi, had not been separated from each other. In dendrogram triticale of spring form significantly separated from winter form triticale cultivars. An average value of PIC and DI indicate that used SSR markers are moderately polymorphic. We can recommend all rye SSR markers used for diversity analysis accept one marker (SCM43) which reached considerably unfavourable results of PIC and DI values. Anyway, used rye SSR markers represent an efficient and useful marker system for detection of genetic variability in closed-related triticale.

Acknowlegments: This work was funded by European Community under project No. 26220220180: Building Research Centre „AgroBioTech” (50\%) and KEGA project No 021SPU-4/2015 (50\%). This work originated also thanks to the support within Operational Programme Research and Development for the project: "Transfer, use and dissemination of research results of plant genetic resources for food and agriculture" (ITMS: 26220220058), cofinanced from the resources of the European Union Fund for Regional Development.

\section{REFERENCES}

Balážová, Ž., Trebichalský, A., Gálová, Z., Hornyák Gregáňová, R. (2015). Application of wheat SSR markers for detection of genetic diversity in triticale (x $\begin{array}{llll}\text { Triticosecale witt). } & \text { Genetika, } & 47, & 983\end{array}$

$-992$. http://dx.doi.org/10.2298/gensr1503983b

Balážová, Ž., Petrovičová, A., Gálová, Z., Vivodík, M. (2016). Molecular characterization of rye cultivars. Potravinárstvo, 10 (1), 54-58. http://dx.doi.org/10.5219/522

Bassam, B.J., Caetano-Anolles, G., P.M. Gresshoff. (1991). Fast and sensitive silver staining of DNA in polyacrylamide gels. Analytical Biochemistry, 196, 8083. http://dx.doi.org/10.1016/0003-2697(91)90120-i

Benor, S., Zhang, M., Wang, Z., Zhang, H. (2008). Assessment of genetic variation in tomato (Solanum lycopersicum $\mathrm{L}$.) inbred lines using SSR molecular markers. Journal of Genetics and Genomics, 35, 373- 379. http://dx.doi.org/10.1016/s1673-8527(08)60054-5

Bickel, C.L., Gadani, S., Lukacs, M., C.A. Cullis. (2011). SSR markers developed for genetic mapping in flax (Linum usitatissimum L.). Research and Reports in Biology, 2, 23-29. http://dx.doi.org/10.2147/rrb.s16091

Botes, W.C., Bitalo, D. (2013). Identification, evaluation and optimalization of a minimum simple sequence repeat marker set for triticale breeding. Journal of Apllied Biology and Biotechnology, 1, 16-23.

Da Costa, C.T., Albuquerque, A.Ch.S., Nascimento, A., Marcelino, F.C., Pereira, J.F. (2007). Genetic diversity of Brazilian triticales evaluated with genomic wheat microsatellites. Pesquisa Agropecuária Brasileira, 42, 1577-1586. http://dx.doi.org/10.1590/s0100-204x2007001100009

Gregáňová, Ž., Kraic, J., Gálová, Z. (2005). Effectiveness of microsatellites in differentiation of elite wheat cultivars. Biologia , 60, 665-670.

Huang, X.Q., Börner, A., Röder, M.S., Ganal, M.W. (2002). Assessing genetic diversity of wheat (Triticum aestivum L.) germplasm using microsatellite 
markers. Theoretical Applied Genetics, 105, 699-707. http://dx.doi.org/10.1007/s00122-002-0959-4

Hudcovicová, M., Ondreičková, K., Hauptvogel, P., Kraic, J. (2013). Genetic diversity in domestic and introduced wheats. Agriculture (Polnohospodárstvo), 59, 101-110. http://dx.doi.org/10.2478/agri-2013-0009

Ignjatovic-Micic, D., Ristic, D., Babic, V., Andjelkovic, V., Vancetovic, J. (2015). A simple SSR analysis for genetic diversity estimation of maize landraces. Genetika, 47, 53-62. http://dx.doi.org/10.2298/gensr1501053i

Jiang, S.K., Huang, C., Zhang, X.J., Wang, J.Y., Chen, W.F., Xu, Z.J. (2010) Development of Highly Informative Microsatellite (SSR) Marker Framework for Rice (Oryza sativa L.) Genotyping. Agricultural Sciences in China, 9, 16971704. http://dx.doi.org/10.1016/s1671-2927(09)60268-6

Khlestkina, E.K., Than, M.H.M., Pestsova, E.G., Röder, M.S., Malyshev, S.V., Korzun, V., Börner, A. (2004). Mapping of 99 new microsatellite-derived loci in rye (Secale cereale L.) including 39 expressed sequence tags. Theoretical Applied Genetics, 109, 725-732. http://dx.doi.org/10.1007/s00122-004-1659-z

Korkovelos, A.E., Mavromatis, A.G., Huang, W.G., Hagidimitriou, M., Giakoundis, A., Goulas, C.K. (2008). Effectiveness of SSR molecular markers in evaluating the phylogenetic relationships among eight Actinidia species. Scientia Horticulturae, 116, 305-310. http://dx.doi.org/10.1016/j.scienta.2008.01.011

Kuleung, C., Baenziger, P.S., Dweikat, I. (2004). Transferability of SSR markers among wheat, rye and triticale. Theoretical and Applied Genetics, 108, 11471150. http://dx.doi.org/10.1007/s00122-003-1532-5

Kuleung, C., Baenzinger, P.S., Kachman, S.D., Dweiket, I. (2006). Evaluating the Genetic Diversity of Triticale with Wheat and Rye SSR Markers. Crop Science, $\quad 46, \quad 1692-1700 . \quad$ ISSN $1435-0653$. http://dx.doi.org/10.2135/cropsci2005.09-0338

Leonova, I.N., Dobrovolskaya, O.B., Kaminskaya, L.N., Adonina, I.G., Koren, L.V., Khotyljova, L.V., Salina, E.A. (2005). Molecular analysis of the triticale lines with different vrn genes systems using microsatellite markers and hybridization in situ. Russian journal of Genetics, 41, 1014-1020. http://dx.doi.org/10.1007/s11177-005-0193-7

Ondroušková, J., Vyhnánek, T. (2013). Study of genetic variability of triticale varieties by SSR markers. Journal of Microbiology, Biotechnology and Food Sciences, $\quad 2, \quad 2366-2368 . \quad$ http://www.jmbfs.org/wpcontent/uploads/2013/04/jmbfs_0369_ondrouskova.pdf

Paetkau, D., Calvert, W., Stirling, I., Strobeck, C. (1995). Microsatellite analysis of population structure in Canadian polar bears. Mol. Ecol, 4, 347-354. http://dx.doi.org/10.1111/j.1365-294x.1995.tb00227.x

Peng, J.H., Fahima, T., Röder, M.S, Li, Y.C., Dahan, A., Grama, A., Ronin, Y.I. Korol, A.B., Nevo, E. (1999). Microsatellite tagging of the stripe-rust resistance gene YrH52 derivedfrom wild emmer wheat, Triticum dicoccoides, and suggestive negative crossover interference on chromosome 1B. Theoretical Applied Genetics, 98, 862-872. http://dx.doi.org/10.1007/s001220051145

Pestsova, E., Ganal, M.W., Röder, M.S. (2000). Isolation and mapping of microsatellite markers specific for the D genome of bread wheat. Genome, 43, 89-697. http://dx.doi.org/10.1139/gen-43-4-689

Röder, M.S., Plaschke, J., König, S.U., Börner, A., Sorrels, M.E., Tanksley, S.D., Ganal, M. (1995). Abundance, variability and chromosomal location of mocrosatellites in wheat. Molecular Genetics and Genomics, 246, 327-333. http://dx.doi.org/10.1007/bf00288605

Saal, B., Wricke, G. (1999). Development of simple sequence repeat markers in rye (Secale cereale L.). Genome, 42, 964-972. http://dx.doi.org/10.1139/gen-425-964

Salem, K.F.M., El-Zanaty, A.M., Esmail, R.M. (2008). Assessing wheat (Triticum aestivum L.) genetic diversity using morphological characters and microsatellite markers. World Journal of Agricultural Sciences, 4, 538-544.

http://citeseerx.ist.psu.edu/viewdoc/download?doi=10.1.1.415.1802\&rep=rep1\&t ype $=$ pdf

Salmanovicz, B.P., Langner, M., Wiśniewska, H., Apolinarska, B., Kwiatek, M., Błaszczyk, L. (2013). Molecular, Physicochemical and Rheological Characteristics of Introgressive Triticale/Triticum monococcum ssp. Monococcum Lines with Wheat 1D/1A Chromosome Substitution. International Journal of Molecular Sciences, 14, 15595-15614. http://dx.doi.org/10.3390/ijms140815595

Tams, S.H., Bauer, E., Oettler, G., Melchinger, A.É. (2004). Genetic diversity in European winter triticale determined with SSR markers and coancestry coefficient. Theoretical and Applied Genetics, 108, 1385-1391. http://dx.doi.org/10.1007/s00122-003-1552-1

Vaillancourt, A., Nkongolo, K.K., Michael, P., Mehes, M. (2007). Identification, characterisation, and chromosome locations of rye and wheat specific ISSR and SCAR markers useful for breeding purposes. Euphytica, 159, 297-306. http://dx.doi.org/10.1007/s10681-007-9492-5

Vyhnánek, T., Nevrtalová, E., Slezáková, K. (2009). Detection of the genetic variability of triticale using wheat and rye SSR markers. Cereal Research Communications, 37, 23-29. http://dx.doi.org/10.1556/crc.37.2009.1.3

Weber, J. L. (1990). Informativeveness of human (dC-dA)n x (dG-dT)n polymorphism. Genomics, 7, 524-530. http://dx.doi.org/10.1016/08887543(90)90195-Z

Weir, B.S. (1990). Genetic data analysis. Sinauer Associated, Sunderland, Mass. 